\title{
I. VESPERS
}

\section{Structure of the Vespers of the Presanctified Liturgy in the Manuscripts of the Old Russian Recension}

We should mention the main elements in the description of the Vespers of the Presanctified Liturgy, which appear in the service books of the Old Russian recension. Typically, the ordinance of the Presanctified Liturgy starts with the Vesperal Entrance with the censer: the regular "prayer of the Entrance" in the Vespers, "At evening, at morning and at midday we praise...," and singing of the Hymn, "O gentle Light ..." Then the ordinance mentions the Prokeimena, the Paroemias (readings from the Old Testament), as well as instructions on liturgical actions which occur only during the Vesperal part of the Presanctified Liturgy: "the rite of Light" - the exclamation of the clergyman who is holding the light, "The Light of Christ shines for all," and a particular singing of "Let my prayer arise...," and "Let Israel hope in the Lord..." consisting of the verses of Psalms 140 and 130, accordingly.

According to the description of the ordinance of the Vespers of the Presanctified Liturgy, all service books of the Old Russian recension can be divided into four groups, each containing four manuscripts. Group 1 consists of service books Syn. 604, Sof. 518, Sof. 519, Sol. 1016/1125; group 2 consists of manuscripts Sof. 525, Sof. 526, Rum. 399, Sin typ. 40; group 3 consists of manuscripts Sof. 521, Syn. 892, YaMZ 15472, Rogozh. kladb. 566; and group 4 consists of manuscripts O.p. I.4, O.p. I.5, Syn. typ. 43, Syn. 598, and the service book Slav. 1.

First of all we will consider the structure of the ordinance for the Vespers of the Presanctified Liturgy from the manuscripts of the latter group. The service books from the fourth group include the manuscripts with the most detailed description of the Vespers. Moreover, only the manuscripts of this group contain the structure of the Vesperal part of the Presanctified Liturgy twice: first for Cheese-fare Week that precedes Great Lent, and then for Lent itself.

According to the Jerusalem rule, which has regulated the divine service of the Russian Orthodox Church from the late fourteenth century until now, the Liturgy of the Presanctified Gifts is served only during Great Lent and Holy Week; Wednesday of the first week of Lent is the first day for performing the Liturgy. However, Slavonic liturgical texts of the thirteenth-fifteenth centuries preserve evidence of serving the Liturgy of the Presanctified Gifts also during Cheese-fare Week. Besides the service books, instructions to serve the Presanctified 
Liturgy during this week, can be found in the Slavonic Typica, Triodia, and the Books of Paroemias, ${ }^{48}$ but the service books belonging to the fourth group describe the order of the Vesperal part of the Presanctified Liturgy for Cheese-fare Week in greatest detail.

The custom of performing the Presanctified Liturgy on Wednesday and Friday of Cheese-fare Week is reflected not only in the texts of the Studite type, but also in the manuscripts, which describe the office of the cathedral church (the Great Church or the Church of Hagia Sophia in Constantinople). All three known manuscripts of the Typikon of the Great $\mathrm{Church}^{49}$ mention serving the Presanctified Liturgy during Cheese-fare Week, yet some parts of the liturgical rite are described in these manuscripts in different ways. Therefore, the brief description of the ordinance for the Vespers of the Presanctified Liturgy during Cheese-fare Week from the Slavonic sources serves as valuable historical evidence supplementing the Greek sources. The order of the Vespers of the Presanctified Liturgy for the period of Cheese-fare week from the manuscripts of the fourth group is schematically presented in Table 1. Here and below in the Tables, the sign " + " denotes the existence of a certain element in the manuscript, and the sign "-" denotes the absence of such an element.

(48) The instructions concerning the performance of the Presanctified Liturgy during Cheese-fare week can be found, for example, in the Slavonic Typica Syn. 330 (fol. 6), Syn. 333 (fol. 95), Syn. 905 (fol. 158v) from the State Museum of History, in the Triodion Pog. 40 (fol. 21v) from the National Library of Russia, in the books of Paroemias O.p. I.13 (fol. 24v, fol. 27) from the National Library of Russia, Syn. typ. 49 (fol. 13v), Syn. typ. 51 (fol. 19v) from the Russian State Archives of Ancient Acts. The history of performing the Liturgy of the Presanctified Gifts on Wednesday and Friday of Cheese-fare week in Rus' was discussed in detail in the study: Дисицин, Первоначальный славяно-русский типикон..., 56-69. We should note that besides the Typica of the Studite type, the Typikon of the Great Church also instructs serving the Liturgy of the Presanctified Gifts on Wednesday and Friday of Cheese-fare week (concerning the regulations of the Typikon of the Great Church for Cheese-fare week, see below, p. 24).

(49) Jerusalem manuscript (10-11 C.): Mateos, Le Typikon de la Grande Église..., 6-8; Patmos manuscript (9-10 С.): А. А. ДмитриЕвский, Описание литургических рукописей, хранящихся в библиотеках Православного Востока, т. 1: Төтєка́ (Киев, 1895) 111-112, Dresden manuscript: Дисицин, Первоначальный славяно-русский типикон..., 61-63. 
Table 1.

The Structure of the Vespers in the Old Russian Recension

\begin{tabular}{|l|l|l|l|l|l|}
\hline & $\begin{array}{l}\text { Syn. } \\
\text { 98 }\end{array}$ & $\begin{array}{l}\text { O.p. } \\
\text { I.4 }\end{array}$ & $\begin{array}{l}\text { O.p. } \\
\text { I.5 }\end{array}$ & $\begin{array}{l}\text { Syn. } \\
\text { typ. } 43\end{array}$ & Slav. 1 \\
\hline Prayer of the Entrance & + & + & + & + & + \\
"O gentle Light ..." & + & + & + & + & + \\
Prokeimenon & + & - & + & + & + \\
Paroemia & + & + & + & + & + \\
"Let Israel hope in the Lord..." & + & + & + & + & + \\
\hline
\end{tabular}

First of all, we should note the lack of "the rite of light," and the exclamation, "The Light of Christ enlightens all" in the service books that belong to the fourth group..$^{50}$ According to the evidence contained in the manuscripts of the fourth group, the singing of "Let my prayer arise..." at the Vespers of the Presanctified Liturgy during Cheese-fare Week was replaced by the singing of "Let Israel hope in the Lord...." Similarly, the absence of the exclamation, "The Light of Christ..." may indicate a conjoint emergence of "Let my prayer arise..." and "The Light of Christ..." in the service of the Presanctified Liturgy, which is consistent with the view of Winkler on Constantinopolitan borrowing of elements from the Antiochean Vespers. ${ }^{51}$ However, we should also note that the exclamation "The Light of Christ..." on Wednesday of Cheese-fare week is mentioned in the Dresden manuscript of the Typikon of the Great Church, ${ }^{52}$ moreover, according to the description of this Wednesday service, the exclamation "The Light of Christ..." is

(50) The Bulgarian Codex Pogodinskaya Triodion (Ms Pog. 40, fol 21v from the National Library of Russia, first half of the 14th C.) also contains an indication on the absence of the exclamation "The Light of Christ..." during

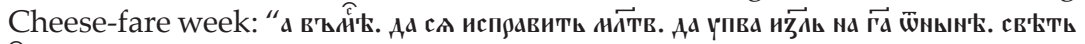

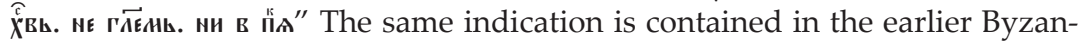
tine texts, for example, in the entry at the service on Wednesday of Cheesefare week from the Evergetis Typikon (Ms of the Typikon of the Most-Holy Theotokos the Benefactor (Evergetis) Monastery): Дмитриввский, Описание

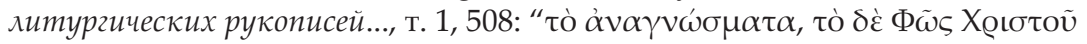

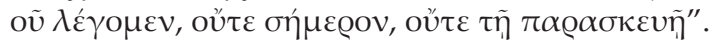

(51) WinkLeR, Der geschichtliche Hintergrund..., 205.

(52) Аисицин, Первоначальный славяно-русский типикон..., 62: “ІІбте́оv,

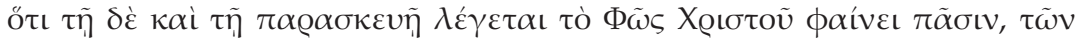

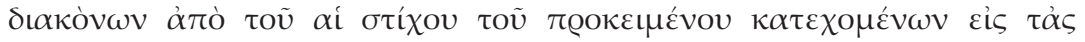

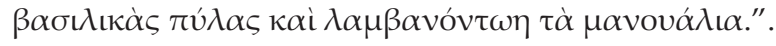


made after the first verse of the Prokeimenon. ${ }^{53}$ (The Jerusalem and the Patmos manuscripts of the Typikon of the Great Church do not contain an indication of the exclamation "The Light of Christ..." in the service of Cheese-fare week. ${ }^{54}$ )

During Great Lent the manuscripts belonging to the fourth group prescribe the order of the Vespers that can be summarized in the following Table:

Table 2.

\begin{tabular}{|l|l|l|l|l|l|}
\hline & $\begin{array}{l}\text { Syn. } \\
598\end{array}$ & $\begin{array}{l}\text { O.p. } \\
\text { I.4 }\end{array}$ & $\begin{array}{l}\text { O.p. } \\
\text { I.5 }\end{array}$ & $\begin{array}{l}\text { Syn. } \\
\text { typ. } 43\end{array}$ & Slav. 1 \\
\hline Prayer of the Entrance & - & + & + & - & + \\
“Ogentle Light..." & - & - & + & + & + \\
Prokeimenon & + & + & + & + & + \\
Paroemia & + & + & + & + & + \\
Prokeimenon & + & - & + & + & - \\
"The Light of Christ..." & + & + & + & + & + \\
Paroemia & + & + & + & + & + \\
"Let my prayer arise ..." & + & + & + & + & + \\
\hline
\end{tabular}

The structure of the Vespers from Table 2 coincides with the modern order of the Vespers of the Presanctified Liturgy in the part that starts with the Entrance and ends with singing "Let my prayer arise..."

As opposed to the fourth group of manuscripts, the rest of the service books of the Old Russian recension describe the Vespers of the Presanctified Liturgy in lesser detail. The first group consists of the earliest manuscripts of the thirteenth century. The manuscripts of the first group do not contain instructions on what actions are performed

(53) For the Wednesday of Cheese-fare Week, the Dresden Typikon indicates that the Prokeimenon "Save me, O God, by thy name..." with two verses "Hear my prayer, O God..." and "Behold, God is my helper..." should be performed on Wednesday of Cheese-fare Week (Лисицин, Первоначальный славяно-русский типикон..., 62). The Jerusalem and the Patmos manuscripts of the Typikon of the Great Church prescribe performing the same Prokeimenon on Wednesday of Cheese-fare Week but only with the first verse: Mateos, Le Typikon de la Grande Église..., 8.

(54) The Jerusalem manuscript and the Typikon Paris gr. 1587 (12th C.) mention the exclamation, "The Light of Christ..." for March 9, for the service for the Forty Martyrs of Sebaste, in the case when this service falls during the period of Great Lent; the Patmos manuscript does not have the exclamation, "The Light of Christ ..." in the service for March 9: Mateos, Le Typikon de la Grande Église..., 246. 
only during Cheese-fare Week and what actions are performed during Great Lent, but their description of the Vespers of the Presanctified Liturgy has certain liturgical elements that correspond both to the ordinance of the Vespers for Cheese-fare Week and for the ordinance of the Vespers for the period of Great Lent. The manuscripts of the fourteenth century constitute the second and the third group. The second group includes service books with the most concise description of the Vespers, which, notably, do not mention the rite of light as well as singing "Let Israel hope in the Lord...", that is, the liturgical elements corresponding to Cheese-fare Week. ${ }^{55}$

The structure of the description for the ordinance of the Vespers of the Presanctified Liturgy in the manuscripts of the second group is shown in Table 3.

Table 3.

\begin{tabular}{|l|l|l|l|l|}
\hline & Sof. 525 & Sof. 526 & $\begin{array}{l}\text { Syn. } \\
\text { typ. 43 }\end{array}$ & $\begin{array}{l}\text { Rum. } \\
399\end{array}$ \\
\hline Prayer of the Entrance & + & + & - & + \\
"O gentle Light..." & + & + & - & + \\
Prokeimenon & + & - & + & + \\
Paroemia & + & + & + & + \\
"Let Israel hope in the Lord..." & + & + & + & + \\
\hline
\end{tabular}

Naturally, if the service book does not mention a certain liturgical action, this does not mean that this action was not performed during the service. Therefore, the comparison of brief rubrics in the service books of the second group with significantly more detailed description of the Vespers in the service books of the fourth group shows a difference not in the liturgical rite, but in the form of recording the rite in a manuscript. The lack of a unified structure for describing Vespers in the manuscripts of the Old Russian recension shows that the rubrics, corresponding to this part of the ordinance of the Presanctified Liturgy, apparently did not exist in the Greek originals of the Old Slavonic service books belonging to the Old Russian recension, and the scribes supplemented the missing rubrics themselves, with varying degrees of completeness.

(55) Nevertheless, in the manuscripts of this group, as well as other manuscripts of the Old Russian recension, the ordinance of the Presanctified Liturgy starts with the instruction that this Liturgy should be served starting on Cheese-fare Wednesday. 
The order of the Vespers of the Presanctified Liturgy for the manuscripts belonging to the third group, is shown in Table 4 .

Table 4.

\begin{tabular}{|l|l|l|l|l|}
\hline & Sof. 521 & YaMZ & $\begin{array}{l}\text { Syn. } \\
15472\end{array}$ & $\begin{array}{l}\text { Rogozh. } \\
\text { kladb. } 566\end{array}$ \\
\hline Prayer of the Entrance & - & + & - & + \\
"O gentle Light ..." & - & + & + & + \\
Prokeimenon & - & + & + & + \\
Paroemia & + & + & + & + \\
"The Light of Christ ..." & + & + & + & + \\
Paroemia & + & + & + & + \\
"Let Israel hope in the Lord..." & - & + & - & + \\
"Let my prayer arise ..." & + & + & + & + \\
\hline
\end{tabular}

We should note that although the service books from the third group, in contrast to the manuscripts from the fourth group, do not have a double description of the ordinance of the Vespers (separately for Great Lent, and for Cheese-fare Week), the manuscripts YaMZ 15472 and Rogozh. kladb. 566 contain instructions on performing "Let my prayer arise..." for the period of Great Lent and "Let Israel hope in the Lord..." during Cheese-fare Week (these manuscripts do not have the instruction on the absence of the exclamation, "The Light of Christ..." during Cheese-fare Week).

The structure of the ordinance of the Vespers of the Presanctified Liturgy in the service books of the first group is shown in Table 5. The sign " $*$ " in the Table marks those parts of the Vespers that are mentioned only in the margins of the manuscript.

Table 5.

\begin{tabular}{|l|l|l|l|l|}
\hline & $\begin{array}{l}\text { Syn. } \\
604\end{array}$ & $\begin{array}{l}\text { Sol. 1016/ } \\
1125\end{array}$ & Sof. 518 & Sof. 519 \\
\hline Prayer of the Entrance & + & + & - & + \\
\hline “O gentle Light ..." & - & + & + & + \\
\hline Prokeimenon & + & + & + & + \\
\hline Paroemia & + & + & + & $+*$ \\
\hline “The Light of Christ ..." & + & - & + & $+*$ \\
\hline Paroemia & + & - & + & $+*$ \\
\hline
\end{tabular}




\begin{tabular}{|l|l|l|l|l|l|}
\hline "Let Israel hope in the Lord..." & + & + & - & - \\
\hline "Let my prayer arise ..." & - & + & $+*$ & $+*$ \\
\hline
\end{tabular}

At first sight it might seem that there is a discrepancy between the worship practices of Old Rus' and the practices described by the Byzantine sources: the earliest manuscripts of the thirteenth century reflect a different type of ending of the Vespers that was replaced later, in the fourteenth century, by the ending recorded in later sources. The service books from the first group either omit the instruction on singing "Let my prayer arise...," (Syn. 604) insert it on the margins of the manuscript (Sof. 518, Sof. 519), ${ }^{56}$ or list it together with "Let Israel hope in the Lord..." (Sol. 1016/1125) without mentioning the time of its performance (during Great Lent or during Cheese-fare Week). However, it is likely that this feature does not refer to the ritual but to the method of its recording. It is unlikely that singing "Let my prayer arise..." was absent in the original Russian Church tradition.

Thus, the most interesting evidence of the Slavonic service books is related to the ordinance of the Vespers of the Presanctified Liturgy on Wednesday and Friday of Cheese-fare Week. Byzantine manuscripts that contain information about the Presanctified Liturgy during Cheese-fare Week, firstly, are few in number, and, secondly, their data is not always consistent among various manuscripts. The Evergetis Typikon (note 50) and the Dresden manuscripts of the Typikon of the Great Church (note 52) answer one of the key questions, that is, whether the "rite of light" was performed at the Vespers of the Presanctified Liturgy during Cheese-fare Week, in a different way. Out of seventeen manuscripts of the Old Russian recension, the most complete and clear liturgical instructions concerning the order of serving the Vespers of the Presanctified Liturgy are contained in the fourth group of manuscripts. The evidence of these five Slavonic manuscripts of the fourteenth century coincides with the indication of the Evergetis Typikon on the lack of the exclamation, "The Light of Christ..." in the service of the Presanctified Liturgy during Cheesefare Week. Fragmentary liturgical instructions, contained in the re-

(56) We should note that in the manuscript Sof. 519, the instructions on the exclamation, "The Light of Christ..." and singing "Let my prayer arise..." appear on the margins of the manuscript and probably are later additions to the text. ("Let my prayer arise..." in the Ms. Sof. 518, was most likely added by the scribe of the manuscript). 
maining twelve manuscripts, do not allow us to recognize any particular pattern.

The disagreement between the rubrics that describe the Vespers of the Presanctified Liturgy, is one of the main features of the Old Russian recension. On the one hand, the omission of a certain liturgical element in the text of a service book does not necessarily mean the absence of this element in liturgical practice, but, on the other hand, we cannot rule out the possibility that the description of Vespers of the Presanctified Liturgy in the service books of the thirteenth-fifteenth centuries reflects local liturgical traditions. However, the small number of sources usually does not allow us to draw any conclusions about local liturgical traditions with certainty. Thus, none of the service books from the collection of the Novgorod Cathedral of St. Sophia contains the hymn, "Let Israel hope in the Lord...," but this did not lead to the absence of singing "Let Israel hope in the Lord..." in the liturgical practice of Novgorod churches. The singing of this Prokeimenon during Cheese-fare Week is indicated in the Zakharinsky Book of Paroemias (Ms. O.p. I.13 from the Russian State Library), and on the fol. 73 of the Book, the scribe left a note indicating that this Book of Paroemias was written for one of the Novgorod churches. ${ }^{57}$

\section{Text of Vespers of the Liturgy of the Presanctified Gifts in the Manuscripts of the Old Russian Recension}

The ordinance of the Vespers in the manuscripts of the Old Russian recension begins with the instruction on the Vesperal Entrance. Almost all service books of the Old Russian recension contain the instruction on reading the Exit prayer; the service book Sof. 519 contains the full text of the Entrance Prayer, "At evening, at morning and at midday we praise...", and the manuscripts Sol. 1016/1125, Syn. 598, Sof. 525, Sof. 526, O.p. I.4, O.p. I.5, Rum. 398, Syn. typ. 43, and Slav. 1 contain the opening words. The instructions on the performance of "O gentle Light..." are absent only in three manuscripts: Syn. 604, Sof. 521, and Syn. typ. 40 (in the manuscript Sof. 521, free space was left for the title and the beginning of the service of the Presanctified Liturgy, but the scribe of the manuscript never filled the space). Seven service books (Sol. 1016/1125, Sof. 518, YaMZ 15472, Rum. 398, Sof. 526, O.p. I.4, and Syn. typ. 43) provide the indication of singing "O gentle Light..." by

(57) SK, p. 205-206. 
the people..$^{58}$ The remaining six manuscripts contain a method for performing the Hymn, "O gentle Light..." which is not used in modern practice, when the deacon pronounces the initial words (Sof. 519, O.p. I.5, Rogozh. kladb. 566), and sometimes, perhaps, the whole Hymn (Sof. 525, Syn. 598, Syn. 892, Slav. 1)..$^{59}$

Other features of the initial part of Vespers in the service books of the Old Russian recension include the indication for pronouncing the verse of blessing made upon entering the altar, in the manuscript

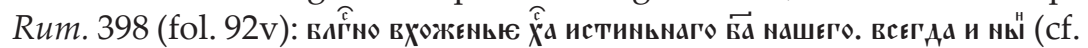
the prayers of the Entrance in the service book Khlud. 117 - see below, p. 29). In some Russian service books of the thirteenth-fourteenth centuries, this verse is assigned to the Entrance during the Vespers (for example, Sof. 518, fol. 2v, Sof. 524, fol. 61v) or for the Small Entrance during the Liturgy of John Chrysostom (for example, Sof. 523, fol. 18r).

After the Entrance, the service books of the Old Russian recension, according to usual practice, indicate the exclamation of the Prokeimena and reading the Paroemias. Some manuscripts specify the Biblical material (Genesis for the first reading in the Sof. 518, Sof. 521, Syn. 598, O.p. I.4, O.p. I.5, and Slav. 1, and Proverbs for the second reading in the Sof. 521, O.p. I.5, and Slav. 1) which is also a traditional feature. We should note that in the combination of the Old Testament readings from both the Slavonic Books of Paroemias and from the Triodia for Cheese-fare Week and the beginning of Great Lent, we did not find deviations from the usual order. ${ }^{60}$

(58) Along with a well established practice of performing the Hymn "O gentle Light..." by the singers, in the fourteenth century there existed a tradition, when the text was recited by a reader. This tradition is reflected, for example, in the rubrics for the Presanctified Liturgy in the Serbian manuscripts of the fourteenth century: Dečani 119, Dečani 121, Dečani 122, Dečani 123, Krušdol Zh IV64, Hilandar 316, Čorovič J 7.

(59) The method of performing the Hymn by reciting the initial words of "O gentle Light..." by the deacon and singing the rest of the Hymn by the choir, in the fourteenth century was used not only at the Presanctified Liturgy but during the regular Vespers. (see, for example, the Sof. 523, fol. 51r). This method was used until the seventeenth century, and is indicated in the ordinance of the Presanctified Liturgy from some of the old-printed service books (see, for example, Служебник (Москва, 1623) 190).

(60) The Book of Paroemias O.p. I.13 from the National Library of Russia, in contrast to regular practice, prescribes reading Isaiah as a reading for Cheesefare Week. Yet the text of the Paroemia is, in fact, the reading from the Book of Joel, traditional for Cheese-fare Week. The Typika Syn. 330 (fol. 6), Syn. 333 
The indication about the exclamation "The Light of Christ..." is missing in the manuscript Sol. 1016/1125, and in all four service books of the second group. The service books of the first group do not provide this indication for the period of Cheese-fare Week. Most of the service books that contain the "rite of light" (Syn. 604, YaMZ 15472, Syn. 892, Sof. 521, O.p. I.4, O.p. I.5, Rum. 398) indicate the custom of pronouncing the exclamation "The Light of Christ..." not by the priest or the bishop, as it is done now, but by the deacon. ${ }^{61}$ This custom goes back to the practice of the Church of Hagia Sophia in Constantinople ${ }^{62}$ and, despite its wide circulation in the cathedral order of service, ${ }^{63}$ later it was completely abolished. We should note that although the Codex O.p. I.5, indicates that the "rite of light" was most likely performed by the deacon, the manuscript allows for another interpretation: joint performance of the "rite of light" by the deacon and the reader (the deacon goes out with the censer and candles, and the reader exclaims "The Light of Christ..."); the practice of pronouncing the exclamation "The Light of Christ..." by the reader is known; it is mentioned, for example, in the Pogodinskaya Triodion (Ms. National

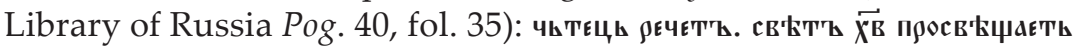
BCA.

Out of the manuscripts belonging to the Old Russian recension, only Sof. 519, Slav. 1 and Syn. typ. 43 indicate that the exclamation "The Light of Christ..." should be made by the priest (from the description of the "rite of light" from the Sof. 518 it is not clear, whether the exclamation "The Light of Christ..." was performed by the priest or by the deacon). However, the Codex Sof. 519 contains a corresponding note

(fol. 95), Syn. 905 (fol. 158v) and the Books of Paroemias Syn. typ. 49 (fol. 13v), Syn. typ. 51 (fol. 19v) prescribe the reading of Prophet Joel for Cheese-fare Week.

(61) On the custom of the exclamation of "The Light of Christ..." performed by the deacon, seе: Аисицин, Первоначальный славяно-русский типикон..., 69-72.

(62) The instruction of the exclamation "The Light of Christ..." performed by the deacon are contained, for example, in the Dresden manuscript of the Typikon of the Great Church (Дмитриввский, Древнейшие патриаршие Типиконьt..., 329) and the description of the Presanctified Liturgy by the Symeon of Thessaloniki (see: PG 155, cols. 656, 657).

(63) Along with Slavonic and Greek texts, Georgian texts also testify to the exclamation of "The Light of Christ..." made by the deacon, see: K. C. KEKEлидзЕ, Аитургические грузинские палятники в отечественных книгохранилищзах (Тифлис, 1908) 104. 
on the margin of the manuscript, and this note may possibly belong to a later time. Apparently, the main reason why the exclamation, "The Light of Christ ..." later became pronounced only by the priest, was the absence of the deacon in some parish churches. This assumption is confirmed by the evidence of the manuscript Syn. 598, fol. 58v: выни А"

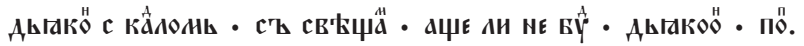

Only seven manuscripts contain the full text of the exclamation. In the Sof. 519, O.p. I.4, Rum. 398, it is exactly the same as the current exclamation; in the Syn. 598, Syn. 892, O.p. I.5, Slav. 1 and Syn. typ. 43, in contrast to the modern practice, the pronoun nы appears at the end of the exclamation.

The Vespers of the Presanctified Liturgy ends with the instruction on singing "Let my prayer arise..." (Ps. 140) and "Let Israel hope in the Lord..." (Ps. 130). The information about singing "Let my prayer arise..." is contained in the Chronicon Paschale for the year 615, which is the first surviving evidence concerning serving the Presanctified Liturgy in Constantinople (see p. 4 and note 1), and in the earliest Greek Euchologia. ${ }^{64}$ In the modern tradition, "Let my prayer arise..." has the form of the Great Prokeimenon: it consists of a refrain (Ps. 140,2) and three verses (Ps. 140,1, 3, 4). The same form, according to the Dresden manuscript of the Typikon of the Great Church (11th C.)., also has "Let

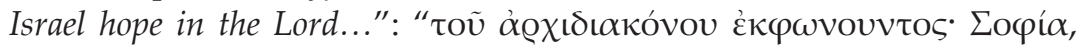

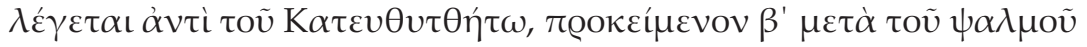

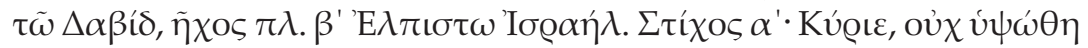

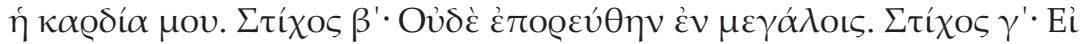
$\mu \eta \dot{\varepsilon} \pi \alpha \pi \varepsilon \iota v o \varphi Q o ́ v o u v " 65$ (after the archdeacon exclaims "Wisdom," he says instead of "Let my prayer arise..." the second Prokeimenon from the Psalm of David in Tone 2: "Let Israel hope in the Lord...," the first verse "My heart is not proud, O Lord...," concern myself with great matters...," 67 the third verse "But I have stilled and quieted my soul..." $\left.{ }^{68}\right)$. The earlier manuscript of the Typikon of Hagia Sophia, Ms. Jerusalem 40 (10th C.), mentions only one verse: "K $\alpha i$

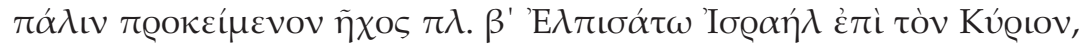

(64) Мораітнг, Н

(65) Дмитриввский, Древнейщие патриаршие Типиконьк.., 329-330.

(66) Ps 130, 1.

(67) Ps 130, 1.

(68) Ps 130, 2. 


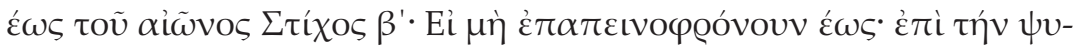
$\chi \eta ் v \mu v^{\prime \prime 69}$.

Having mentioned the refrains, "Let Israel hope in the Lord..." and "Let my prayer arise..." (Ps. 140,2, and Ps. 130,3, respectively), and, in some cases, the first verse (Ps. 140,1 and Ps. 130,1, respectively), the service books of the Old Russian recension, as a rule, do not tell us anything else about these liturgical elements. The exceptions are the manuscript Rogozh. kladb. 566, which contains two verses added to "Let my prayer arise...," and the O.p. I.5 that describes the singing of "Let Israel hope in the Lord...."70

The manuscript Sof. 521, after "Let my prayer arise..." mentions

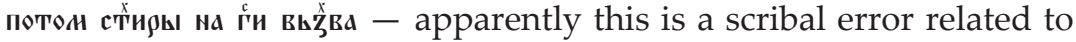
the fact that Psalm 140, 2 was repeated twice during the service of the Presanctified Liturgy, the first time in the beginning of the Vespers, as a part of the "O Lord, I call to you; come quickly to me...," that is, as a part of the regular evening Psalms (Ps. 140, 141, 129, 116), and the second time as a refrain in "Let my prayer arise..."

\section{Manuscripts of the Studite Tradition ${ }^{71}$}

Along with the manuscripts of the Old Russian recension, there exist other service books of the thirteenth-fourteenth centuries that contain instructions on performing the Presanctified Liturgy during Cheese-fare Week, yet the order of the Liturgy, reflected in these manuscripts, corresponds not to the Jerusalem rule but to the earlier liturgical tradition. These manuscripts are represented by service books dated to the end of the thirteenth century: Serbian Q.p. I.68 and Bulgarian Khlud. 117, as well as manuscripts of the early fourteenth century: Bulgarian Uvar. 46 from the State Museum of History, Russian Q.p. I.67,

(69) Mateos, Le Typikon de la Grande Église..., 6. The third manuscript of the Typikon of the Great Church Patmos 226 (9th C.) does not indicate the method for performing "Let Israel hope in the Lord..." (Ibid.).

(70) Several manuscripts of the Studite tradition, which do not belong to the Old Russian recension, contain a fuller description of "Let Israel hope in the Lord..." and "Let my prayer arise..." (see below, p. 31).

(71) We should mention again that the term "the manuscripts of the Studite tradition," as a rule, is applied to the service books that contain an indication for performing the Presanctified Liturgy during Cheese-fare Week but do not belong to the Old Russian recension. 
Serbian Uvar. 574, and the HAZU III $a$ 32.72 This section describes the ordinance of the Vespers of the Presanctified Liturgy on the basis of these six manuscripts. The texts of the Liturgy contained in these Codices, do not belong to a single recension and have substantial differences both in the ordinance composition, and in the texts of the prayers; the name of the ordinance in these manuscripts also differs. In the Q.p. I.67 and Uvar. 46, the Liturgy has a title "вжт'внага слүува стт'о поста .

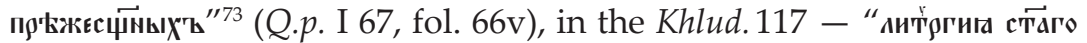

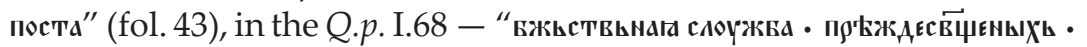

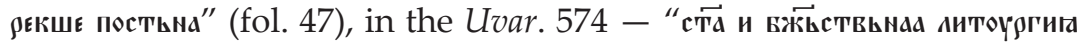

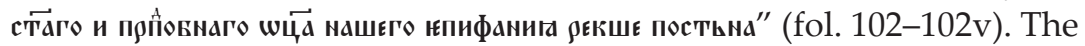
beginning of the ordinance in the manuscript HAZU III $a 32$ is missing. We should note that besides the Uvar. 574, the Presanctified Liturgy is attributed to Epiphanius of Cyprus in several Greek Codices, ${ }^{74}$ in the service book of the fourteenth century Dečani 121 and in some Russian manuscripts of the Presanctified Liturgy of the sixteenth century, for example, the service books Sof. 964, Sof. 1025, and Sof. 1030 from the National Library of Russia. ${ }^{75}$

(72) The beginning of the ordinance of the Presanctified Liturgy in the manuscript HAZU III $a 32$ is missing, but the manuscript has an indirect reference to the ministry of the Liturgy during Cheese-fare week: the presence of singing "Let Israel hope in the Lord..." and the following instruction about

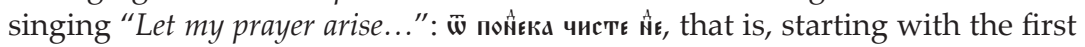
Monday of the Great Lent (similar indication is present in the manuscript Uvar. 574).

(73) In the Uvar. 76 the word пркжєсшиных'ъ is missing.

(74) For example, the Euchologia Vat. gr. 1213, Bodleian Cromwell 11, Na-

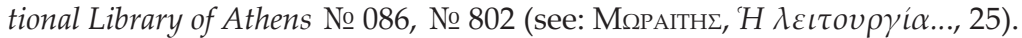

(75) The normal title for the Slavonic service books of the fifteenth-sixteenth centuries is "The Divine Service of the Presanctified [Gifts] by Basil the Great ..." (See, for example, Mss. Syn. 606, Syn. 602, Syn. 618, Syn. 612, Syn. 267 from the State Museum of History, and Mss. Sof. 528, Sof. 529, Sof. 534, Sof. 537, Sol. 1018/1127 from the National Library of Russia, Ms. YaMZ 15471 from the Yaroslavl Reserve-Museum, etc.). However, the attribution of the Presanctified Liturgy to Gregory Dialogus, which corresponds to the indication of modern service books, already has occured in Slavonic manuscripts since the middle of the sixteenth century - the Liturgy of "Gregory, the Pope of Rome," is mentioned in the Acts of the Moscow Council of 1551 (Стоглав, Казань, 1912, p. 43). In connection with the history of the title of the Liturgy, we should mention curious evidence from the Ukrainian manuscript of the sixteenth century from the Library of the Russian Academy of Sciences 21.4.13 (Plichin

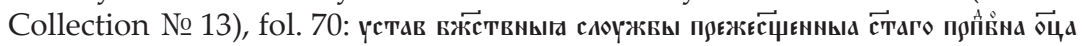


The text of the Vespers of the Presanctified Liturgy in all six manuscripts begins with the initial exclamation of the Liturgy "Blessed is the Kingdom ..."76 that is missing in the service books of the Old Russian recension. After that, the Khlud. 117, Uvar. 46 and Q.p. I. 67 indicate the reading of the Trisagion (the prayer "Holy God ...," "Most Holy Trinity...," "Our Father..."), and after that, all manuscripts indicate the reading of Psalm 103. (As opposed to regular practice, the Khlud. 117 mentions the reading of the Psalm by the deacon and not by the reader).

After the reading of Psalm 103, all six manuscripts list the Prayers at the Lighting of the Lamps and, after them, the Great Litany ("In peace, let us pray to the Lord..."). Seven Prayers at the Lighting of the Lamps are included in the ordinance of the daily Vespers: the priest prays in front of the Royal Gates, making silent Prayers at the Lighting of the Lamps during the reading of Psalm 103. The modern ordinance of the Presanctified Liturgy in this case indicates the reading of only the last four prayers by a priest. The first three prayers are read at small Litanies that conclude the three Antiphons of the Eighteenth Kathisma, which is read after Psalm 103. The text of the Presanctified Liturgy contains only the first three prayers: "O Lord, compassionate and merciful...," "Lord, do not rebuke us in your anger...," and "Lord our God, remember us, sinners..."77

In contrast to the service books of the Old Russian recension that do not contain the Prayers at the Lighting of the Lamps in the text of the Presanctified Liturgy, the rest of the manuscripts of the Studite tradition contain the Prayers at the Lighting of the Lamps after the reading of the Vesperal Psalm (Psalm 103), but the number of these prayers varies in different manuscripts. The manuscript Khlud. 117 contains three prayers, but their traditional order is broken: the first prayer, "O Lord, compassionate and merciful...," and the second prayer, "Lord,

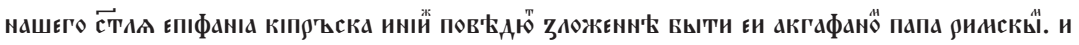

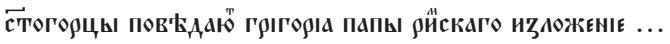

(76) The initial exclamation, "Blessed is the Kingdom ..." is also absent in all

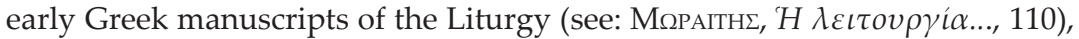
which is one of the signs of an earlier origin for the text of the Old Russian recension, compared to the texts of other manuscripts belonging to the Studite tradition.

(77) Чин божественныя литургии Преждеосвященных, in: Служебник, ч. 2, 421, Божественная литургия Преждеосвященных, in: Ibid., 432-435. 
do not rebuke us in your anger...," are in reverse order. ${ }^{78}$ The service book Q.p. I.67, after citing three regular prayers, adds at this place of the text the Prayer, "At evening, at morning and at midday we praise...," which is usually read during the Entrance. The manuscript Uvar. 574 contains four Prayers at the Lighting of the Lamps; the fourth Prayer from the modern ordinance of the Vespers, "O Lord, who are praised by the holy Powers with never silent hymns..." is added to the first three Prayers. Along with four prayers listed in the Uvar. 574, the manuscript Uvar. 46, similar to the Q.p. I.67, contains the Prayer of the Entrance, "At evening, at morning and at midday we praise..." ${ }^{79}$ The ordinance of the Presanctified Liturgy from the service book Q.p. I.68 contains all seven Prayers at the Lighting of the Lamps of the Vespers. ${ }^{80}$ In the manuscript HAZU III a 32, the beginning of the ordinance of the Presanctified Liturgy is missing. The first folio belonging to the service of the Presanctified Liturgy (fol. 50r), contains the end of the third Prayer at the Lighting of the Lamps "Lord our God, remember us, sinners...," and the fourth Prayer, "O Lord, who are praised by the holy Powers with never silent hymns..." After the Prayers at the Lighting of the Lamps, all six service books contain the Great Litany (the Litany of Peace), which is missing, similar to the Prayers at the Lighting of the Lamps, in the manuscripts of the Old Russian recension.

According to the modern order of the service, after the Prayers at the Lighting of the Lamps, the Psalter (18th Kathisma) is read. At this time the priest makes preparations of the Gifts for the celebration of the Liturgy: he puts the bread on the paten, pours wine and water into the chalice. Out of all the six manuscripts, only the Khlud. 117 and the Uvar. 46 mention the reading of the Kathisma. ${ }^{81}$

(78) Some Greek manuscripts have a similar feature, for example, the Eiletary of the Patmos library № 709 (1260) (А. А. Дмитриввский, Описание литургических рукописей, хранящзихся в библиотеках Православного Востока,

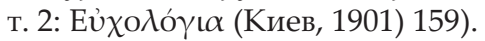

(79) It is possible that the Prayer of the Entrance is indicated in this place of the ordinance for reciting while transferring the Holy Gifts to the Prothesis (cf. further, p. 30).

(80) The indications of the Greek Euchologia on the number of the Prayers at the Lighting of the Lamps are also very different, see: УСпенский, Аитургия Преждеосвященных Даров..., 176.

(81) The Ms. Khlud. 117 only indicates the reading of the Psalter, without the specific number of the Kathismas; the Uvar. 46 indicated the 18th Kathisma. 
Before the indication on the reading of the Psalms in the manuscript Khlud.117, two short prayers are listed, entitled as the prayer of "вьхожекнию," and the prayer of "вьходоу." The first prayer (fol. 44r):

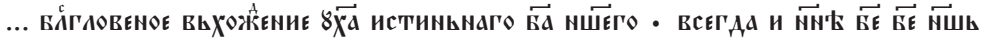

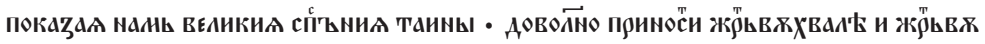

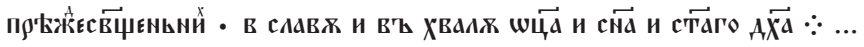

begins with the verse of blessing, "Blessed is the entry of Christ our True God...," found in other service books of the fourteenth century (see page 22). The end of the prayer in other manuscripts is unknown. The second prayer (fol. $44 \mathrm{v}$.):

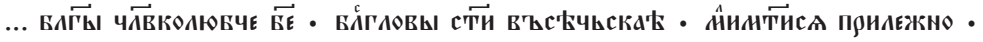

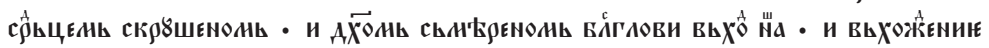

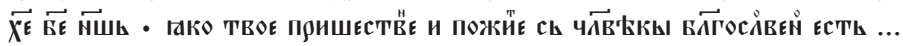

appears in some service books of the fourteenth and fifteenth centuries both in the ordinance of the Vespers of the Presanctified Liturgy, and in the ordinance of the daily Vespers. ${ }^{82}$ Apparently, these prayers were related to the transfer of the Holy Gifts on the Prothesis from the place where the Gifts were kept after their consecration during the full Liturgy. ${ }^{83}$

After reading the Eighteenth Kathisma and singing "Lord, I have cried to you, hear me...," in the modern ordinance of the service the Entrance is made, with the priest and the deacon carrying the censer coming out from the altar and reciting the Entrance Prayer, "At evening, at morning and at midday we praise..." The procession comes into the altar while the Hymn, "O gentle light ..." is performed. The Entrance is described in a

(82) The prayer, "O Good Lover of Mankind..." is present, for example, in the Serbian service books O.p. I. 1116 (fol. 28v), O.p. I. 1117 (fol. 58r), O.p. I. 9 (fol. 64v - fol. 65r), OLDP Q 110 (fol. 25r) from the National Library of Russia, and in the text of the Presanctified Liturgy in the manuscripts Q.p. I.67, Uvar. 46 (see below). In the Hilandar 316 (fol. 114v), the prayer in cited outside of the ordinance of the Vespers and is entitled "the prayer of the Vespers, at the Entrance."

(83) Currently, in accordance with established practice, the Holy Gifts are kept on the altar table, in a special repository, and during the reading of the 18th Kathisma, they are carried to the Prothesis through the High Place. An old-printed service book prescribe that the Gifts should be kept on the Prothesis (seе: ВАнюков, Чин Дитургии Преждеосвященных Даров..., 284-287), but in the manuscripts of the 14th century the location of the Holy Gifts prior to the Liturgy is not specified. 
similar way in the manuscript HAZU III a 32, in the manuscript Uvar. 574, which is close to this service book according to the composition of its ordinance, and in the manuscript Khlud. 117. In the latter Codex,

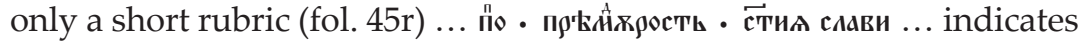
"O gentle light ...," that is, the Khlud.117 contains not the first two words of the Hymn "O gentle light ...," but the next two words. ${ }^{84}$ The manuscripts Q.p. I. 67 and Q.p. I. 68 do not contain the indication of "O gentle light ..." The Q.p. I. 67 contains the Prayer "O Good Lover of Mankind..." as the Entrance Prayer. The manuscript Uvar. 46, after the "Lord, I have

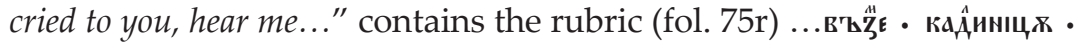

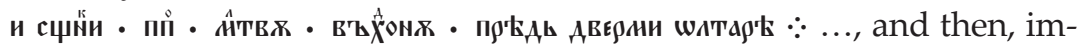

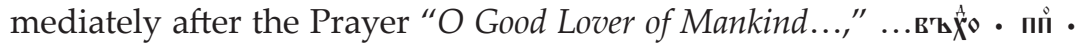

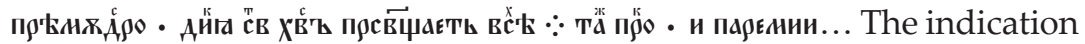
of the exclamation "The Light of Christ ..." by the deacon corresponds to the tradition of the Great Church and to the text of the service books belonging to the Old Russian recension (see p. 23 and note 61).

In the Q.p. I.67 and Q.p. I.68, the "rite of light" (exclamation "The Light of Christ...") is not mentioned, but in the Khlud. 117, "the rite of light"

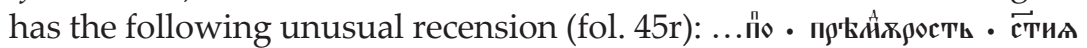

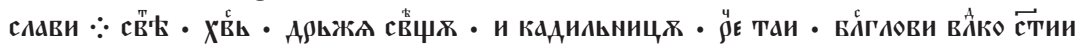
св'ьть . гако ти єси пюосвьчєниє... The unique feature of the manuscript Khlud. 117 is also a lack of indication on reading the Paroemias: Khlud. 117 is the only Slavonic manuscript of the Presanctified Liturgy known to us, that does not provide references to the Old Testament readings. ${ }^{85}$ In the Q.p. I.67, and Q.p. I.68, the Paroemias follow the Entrance, in the Uvar. 46, they follow "The Light of Christ..." The service books HAZU III a 32 and Uvar. 574, in accordance with modern practice, mention the Paroemias two times: before and after "The Light of Christ ..." However, this "rite of light" significantly differs from the modern rite. First of all, both service books require performing the exit from the altar with the

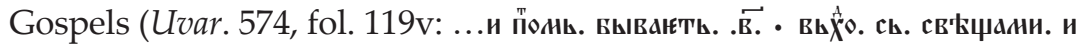
сь. нгүуднвнь ...). ${ }^{86}$ On Wednesday of Cheese-fare Week, the manuscript

(84) It is possibly related to the performance of the Hymn " $O$, gentle Light..." (see, p. 22, and note 59).

(85) The Syn. typ. 42 does not contain any indication of the Paroemias, but in this manuscript, the whole description of the ordinance of the Vespers of the Presanctified Liturgy is omitted, starting with "Lord, I have cried to you, hear me..."

(86) We do not know about other Slavonic manuscripts, which provide an indication on the exit from the altar for the exclamation "The Light of Christ..." 
also requires the Entrance with the Gospels. ${ }^{87}$ Secondly, before the exclamation, "The Light of Christ...," both manuscripts contain the Prayer of the priest, "O Master, Lord our God...," read during the Small Entrance (with the Gospels) during the Liturgy of John Chrysostom.

In the HAZU III a 32 and Uvar. 574, the Vespers of the Presanctified Liturgy end with the indication for singing "Let Israel hope in the Lord..." for the period of Cheese-fare Week, and "Let my prayer arise..." for the period of Great Lent. The service books HAZU III a 32 and Uvar. 574 are the only known Slavonic manuscripts, in which "Let Israel hope in the Lord..." follows the Greek manuscript of the Typikon of the Hagia Sophia, namely, it is sung according to the rite of the Great Prokeimenon with three verses of Psalm 103: ${ }^{88}$

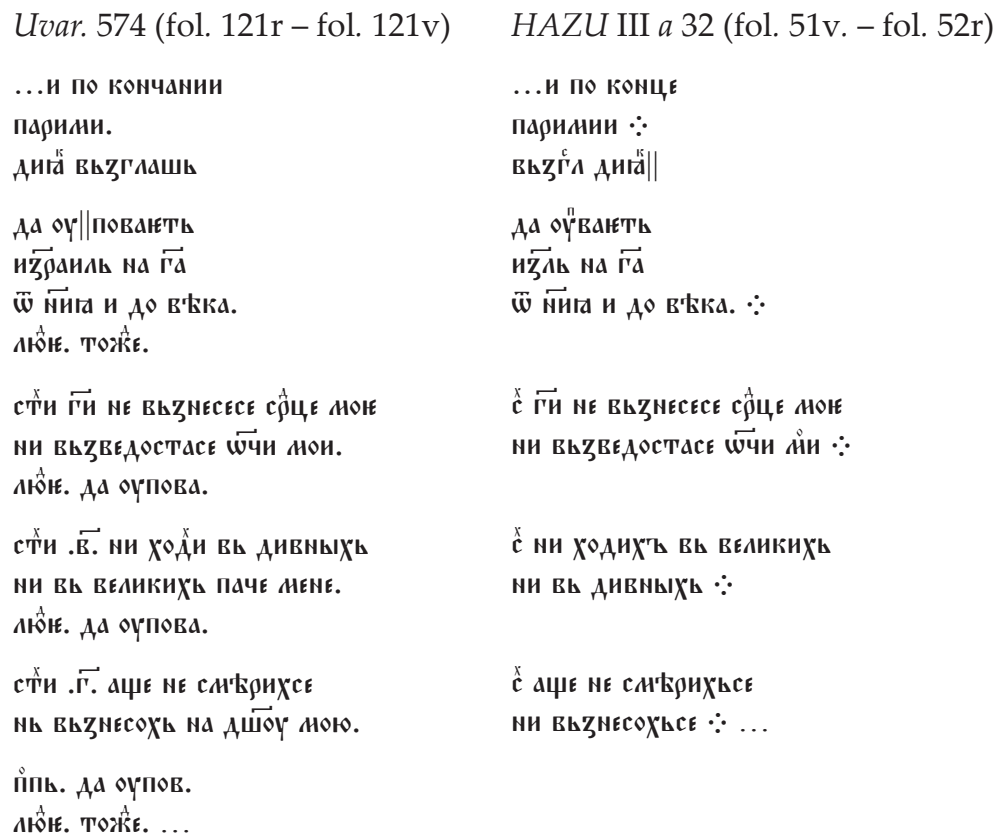

However, there is evidence for the replacement of "the rite of light" by the exit with the Gospels. In the Triodion of the 13th century (manuscript F.n. I.102 from the National Library of Russia), the following instruction about serving the Presanctified Liturgy on Great Friday can be found (fol. 202r): ...и вывӓ́

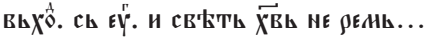

(87) On the evidence of serving the Presanctified Liturgy during Cheesefare Week in the manuscript F.n. I.102, see: Дисицин, Первоначальный славяно-русский типикон..., 59, 73,74.).

(88) См. Дмитриввский, Аревнейщие патриариие Типиконы..., 329-330. 
(cf. the Greek text on p. 24). Note that the HAZU III a 32 and the Uvar. 574 have an indication on exclamation of the verses belonging to this Prokeimenon by the deacon, which is not found in other manuscripts, containing "Let Israel hope in the Lord..." In the service book Uvar. 46, unlike the Uvar. 574 and the HAZU III a 32, the verse "Nor do I concern myself with great matters, or things too wonderful for me..." (Ps 103,1) is absent. In the Uvar. 46, the first verse is "Let Israel hope in the Lord...," the second verse is "God, my heart is not haughty, nor my eyes lofty...," the third verse is "Surely I have stilled and quieted my soul..." Apparently, the difference in the description of the way to perform "Let Israel hope in the Lord..." in the Uvar. 46, compared to the Uvar. 574 and HAZU III a 32, can be explained not by the negligence of the scribe, but with the current liturgical practice, since the performance of "Let Israel hope in the Lord..." is also described in the Book of Paroemias O.p. I.13. We should note that the Slavonic Typikon of the thirteenth century Syn. 330 indicates a different way of performing

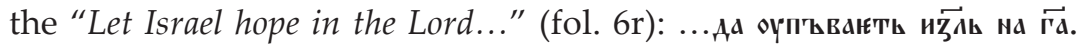

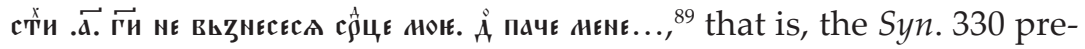
scribes performing "Let Israel hope in the Lord..." not in the form of the Great Prokeimenon (with three verses), but of the regular Prokeimena (with one verse). ${ }^{90}$

In the Q.p. I.68 and Khlud. 117, the singing of "Let Israel hope in the Lord..." is not mentioned, and in the Q.p. I.67 only the first verse "God, my heart is not haughty, nor my eyes lofty..." is mentioned. The performance of "Let Israel hope in the Lord..." in the same form is indicated in the Books of Paroemia of the fourteenth century, Syn. typ. 49 (fol. 13v), and Syn. typ. 51 (fol. 19r) from of the Russian State Archives of Ancient Acts, as well as in the manuscripts of the Old Russian recension Syn. 604, YaMZ 15472, O.p. I.4, O.p. I.5, ${ }^{91}$ and the Rogozh. kladb. 566 (the service books of the Old Russian recension Syn. 598

(89) A similar note is contained in the Typika Syn. 333 (fol. 95r), and Syn. 905 (fol. 158v).

(90) The Syn. 330 prescribes performing the Great Prokeimena for Easter, the Nativity of the Lord, the Baptism of the Lord and for the Matins of Great Saturday (see the section on Great Prokeimena in М. СКАБАлиАНович, Толковый типикон, вып. II (Киев, 1913) 141).

(91) Note that the method of finishing "Let Israel hope in the Lord...," that is described in detail in the O.p. I.5, is not consistent with an indication of the Uvar. 574 on the priest performing the end of this singing. 
and Sol. 1016/1125, referring to "Let Israel hope in the Lord...," do not reveal its contents).

Both the Codex Q.p. I.67 and the earliest Slavonic service book Syn.604 have an indication of "Let Israel hope in the Lord...," but do not mention "Let my prayer arise..." In the other five service books that are considered here, the description of the Vespers ends up with the rubric about "Let my prayer arise..." In the service books that contain "Let Israel hope in the Lord..." (Uvar. 46, HAZU III a 32, Uvar. 574), there is an indication of singing "Let my prayer arise..." starting the first Monday of Great Lent. ${ }^{22}$ The contents of the singing of "Let my prayer arise...," in the service books of the thirteenth-fifteenth centuries, as a rule, are not revealed in detail. The exceptions are the manuscripts Uvar. 46, Uvar. 574, and HAZU III a 32. For example, in the Uvar. 574, (fol. 122v$124 \mathrm{v})$, "Let my prayer arise..." is described as follows:

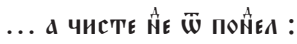

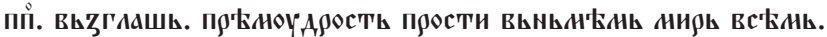

дһ

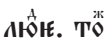

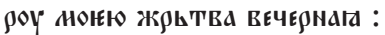

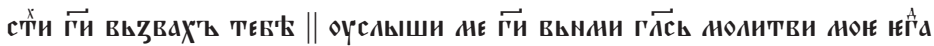

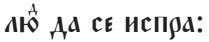

BLZОВY К ТЕБ'

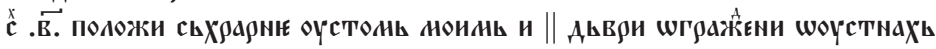

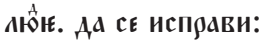

нонуь

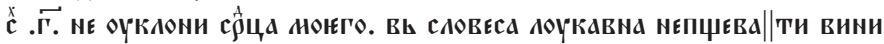

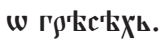

Ad $\mathfrak{C} E$ исח.

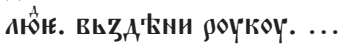

Both, the Uvar. 574 and all other manuscripts that cite "Let my prayer arise...," do not contain deviations from the present order of verses. The HAZU III a 32 and Uvar. 574 provide an indication of the exclamation of the verses in "Let my prayer arise..." by the deacon; other manuscripts do not specify the method of performing "Let my prayer arise..."

(92) According to the modern Typikon, the first day of serving the Presanctified Liturgy is Wednesday of the first week of Great Lent. According to the Studite practice, the Presanctified Liturgy was performed all days of Great Lent starting the first Monday (sеe: Аисицин, Первоначальный славянорусский типикон..., 74-77). 
Concluding the description of the Vespers of the Presanctified Liturgy in the manuscripts in the Studite tradition, we should present the structure for the ordinance of the Vespers of the Presanctified Liturgy in the form of a Table, where the sign " + " indicates the presence of the liturgical element in the ordinance, the sign " " indicates the absence of such references, and the sign " 0 " indicates the lack of relevant pages in the manuscript. Roman numerals designate, respectively, the following manuscripts: I - Q.p. I.68, II - Khlud. 117, III - Uvar. 46, IV Q.p. I.67, V - Uvar. 574, VI - HAZU III a 32.

Table 6.

\begin{tabular}{|c|c|c|c|c|c|c|}
\hline & I & II & III & IV & V & VI \\
\hline "Blessed is the Kingdom..." & + & + & + & + & + & 0 \\
\hline Trisagion & - & + & + & + & - & 0 \\
\hline Psalm 103 & + & + & + & + & + & 0 \\
\hline $\begin{array}{l}\text { Prayers at the Lighting of the } \\
\text { Lamps }\end{array}$ & + & + & + & + & + & + \\
\hline Prayers of the Entrance & - & + & - & - & - & - \\
\hline Great Litany & + & + & + & + & + & + \\
\hline Kathisma & - & + & + & - & - & - \\
\hline $\begin{array}{l}\text { "Lord, I have cried to you, hear } \\
\text { me..." }\end{array}$ & + & + & + & + & + & + \\
\hline Prayer of the Entrance & + & + & + & + & + & + \\
\hline "O gentle light..." & - & + & - & - & + & + \\
\hline Paroemia & + & - & - & + & + & + \\
\hline "The Light of Christ..." & - & + & + & - & + & + \\
\hline Paroemia & - & - & + & - & + & + \\
\hline "Let Israel hope in the Lord..." & - & - & + & + & + & + \\
\hline "Let my prayer arise..." & + & + & + & - & + & + \\
\hline
\end{tabular}

